\title{
Tingkat keparahan halitosis pada manula pemakai gigitiruan
}

\author{
Moh. Dharmautama,* Angela Thomas Koyama,* Astri Kusumawati** \\ *Bagian Prostodonsia \\ **Mahasiswa Tingkat Kepaniteraan \\ Fakultas Kedokteran Gigi Universitas Hasanuddin, Makassar
}

\begin{abstract}
As the increased of age, the mouth commonly becames dried and could cause difficulty either in swallowing foods or using denture. The condition could produced a bad breath (halitosis). Study about halitosis in these people becomes interested because of many people are using denture nowadays. The aim of this study is determinet the effect of using denture in older with the product of halitosis. The study will evaluated how serious the halitosis condition will happened in the correlation between duration of using any kind denture and the product of halitosis.This study perform in Makassar City, consist of fifty people over sixty years old who still using denture with not systemic factors in a non random sampling.

Conclusion, there is $46 \%$ with medium category byusing rub smell and blowsmell detections, use using dentures could produced halitosis, compare with the other kinds of denture, partial denture is the most common couse in produced halitosis, and was influenced by the duration of denture.
\end{abstract}

Key words: Older people, denture, halitosis

\begin{abstract}
ABSTRAK
Seiring dengan bertambahnya umur umumnya mulut menjadi kering, keadaan mulut yang kering dapat menyebabkan kesulitan mengunyah dan menelan makanan atau kesulitan dalam mempergunakan gigitiruan, hal ini dapat menimbulkan bau mulut (halitosis). Melihat banyaknya manula yang memakai gigitiruan, maka dilakukan penelitian halitosis pemakai gigitiruan pada lansia. Penelitian ini ingin mengetahui tingkat keparahan halitosis pada lansia pemakai gigitiruan, lama menggunakan gigitiruan dan timbulnya halitosis, serta apakah jenis gigitiruan mempengaruhi timbulnya halitosis. Penelitian ini dilakukan di wilayah Makassar dengan subjek lansia berumur $\geq 60$ tahun. Cara sampling yang digunakan adalah non random (selektif sampling). Besar sampel 50 orang dengan kriteria pemakai gigitiruan, tidak menderita penyakit sistemik. Dari hasil penelitian dapat disimpulkan bahwa tingkat halitosis dengan deteksi bau usap dan deteksi bau hembus adalah $46 \%$ dengan kategori bau sedang, Pemakaian gigitiruan dapat menyebabkan halitosis, Jenis GTSL lebih banyak menimbulkan halitosis dibanding dengan GTP dan GTJ, Lama pemakaian gigitiruan mempengaruhi munculnya halitosis.
\end{abstract}

Kata kunci: Lansia, gigitiruan, halitosis.

Koresponden: Moh. Dharmautama, Bagian Prostodonsia, Fakultas Kedokteran Gigi Universitas Hasanuddin, Jl. Kandea No.5, Makassar, Indonesia.

\section{PENDAHULUAN}

Halitosis atau bau mulut yang tidak sedap sering menjadi masalah akibat timbul tanpa kita sadari. Jika keadaan ini tidak segera ditangani, selain dapat mengurangi nilai kelancaran komunikasi, juga dapat 
mengganggu penampilan. Meskipun demikian, halitosis bukanlah sejenis penyakit, halitosis hanya gejala dari suatu kelainan/penyakit yang tidak disadari. Insiden halitosis akan meningkat seiring dengan meningkatnya umur, saat puasa. Selain itu, pada keadaan fisiologis, waktu pagi, siang, atau malam hari juga membuat setiap orang berpotensi untuk mengalaminya. ${ }^{1-3}$

Pada keadaan lanjut usia (lansia), biasanya terjadi penurunan tingkat kebersihan mulut, berkurangnya jumlah gigi geligi, dan penurunan sensivitas mukosa rongga mulut terhadap iritasi. Di samping itu terjadi pula pelemahan jaringan penyangga gigi sehingga kemampuan mengunyah berkurang. ${ }^{4}$

Semua perubahan di atas merupakan proses degenerasi yang menyebabkan menurunnya resistensi mukosa. Mukosa mulut menjadi mudah terluka oleh karena makanan yang keras dan adanya gigitiruan yang menyebabkan penyembuhannya agak lambat. Semua keadaan tersebut dapat diperberat karena mulut kering akibat menurunnya produksi saliva. Mukosa yang kering menyebabkan pemakaian gigitiruan tidak adekuat, karena mulut yang kering akan menimbulkan bau napas yang kurang sedap. ${ }^{4}$

Bahan yang hingga saat ini sering digunakan untuk membuat basis gigitiruan adalah resin akrilik karena mempunyai sifat-sifat yang sangat ideal, antara lain adalah warnanya dapat menyerupai mukosa mulut sehingga nilai estetiknya sangat tinggi, mudah pengerjaannya, dan yang paling penting harganya relatif murah. Meskipun demikian, di samping sifat-sifat yang menguntungkan tersebut, resin akrilik juga mempunyai beberapa sifat yang kurang menguntungkan, diantaranya adalah mudah patah bila jatuh pada permukaan yang keras, porus dan dapat menyerap cairan bahan makanan dan minuman, serta menimbulkan bau kurang sedap apabila tidak dijaga kebersihannya dari sisa makanan yang mudah melekat. $^{5}$

\section{Masa lansia}

Proses penurunan fungsi alami pada manusia usia lanjut (manula) merupakan suatu desintegrasi kontrol keseimbangan dan organisasi pada organ atau jaringan yang mulai terjadi pada usia dewasa muda. Pada masa ini terjadi proses menua dari jaringan tubuh yang merupakan keadaan yang wajar terjadi dalam kehidupan manusia. ${ }^{6}$

Masa tua merupakan masa terakhir hidup manusia. Pada masa ini seseorang mengalami kemunduran fisik, mental dan social, sedikit demi sedikit sampai tidak dapat melakukan tugasnya sehari-hari. Pada kebanyakan orang, masa tua itu merupakan masa yang kurang menyenangkan.

\section{Halitosis}

Halitosis berasal dari bahasa Latin, yaitu halitus yang berarti napas dan osis yang berarti keadaan. Jadi halitosis merupakan keadaan dari bau napas, yang umumnya digunakan untuk menunjukkan bau napas yang tidak sedap. ${ }^{5,7}$

Halitosis terjadi oleh berbagai penyebab. Penyebab di dalam mulut yang utama adalah kolonisasi bakteri, baik di lidah, poket, tonsil, permukaan gigi, mukosa pipi, dan sebagainya. Bakteri yang sangat terkait dengan adanya halitosis adalah bakteri anaerob gram negatif, yang dapat mengurai protein menjadi senyawa yang berbau tidak sedap dan mudah menguap. Produk gas yang mudah menguap ini dikenal sebagai volatile sulfur compound (VSC). Adapun jenis mikroorganisme yang tergolong gram negatif penghasil VSC diantaranya adalah Prevotella melanogenica, Fusobacterium nucleatum, Viellonella alcalescence dan Klepsiella pneumoniae. Sementara golongan gram positif seperti Streptococcus sanguis, Streptococcus salivarius, Streptococcus mutans, Lactobacillus naeslundii, Lactobacillus acidophilus, 
Streptococcus aureus, C. albicans, tidak dapat menghasilkan VSC. ${ }^{8-10}$ Aktivitas bakteri anaerob dalam rongga mulut bereaksi dengan protein yang diperoleh dari sisa makanan, sel darah yang mati, bakteri yang mati, ataupun sel epitel yang terlepas dari mukosa mulut. Disamping itu dalam salivapun terdapat subtrat yang mengandung protein.

Sembilan puluh persen kasus halitosis berasal dari dalam mulut, yaitu dari lapisan lidah, celah gingival dan poket periodontal. Selain itu adanya organisme plak menyebabkan pembusukan yang merupakan hasil dari pelepasan chemical volatile terutama kombinasi sulfida (hidrogen sulfida, metil merkaptan, dan dimetil sulfida). ${ }^{11,12}$

Halitosis dapat disebabkan oleh faktor psikologis dan patologis. Faktor psikologis adalah kurangnya aliran ludah selama tidur, makanan/minutan, kebiasaan merokok, dan menstruasi. Sedangkan faktor patologis dibedakan atas penyebab lokal, yaitu kebersihan mulut yang buruk, peridontitis, karies gigi, dry mouth, gigitiruan, dan lidah berambut. Penyebab sistemik halitosis adalah akibat berbagai infeksi atau lesi dari saluran napas, antara lain bronkitis, pneumonia, bronkiektatis; bau dikeluarkan dari jantung ke substansi aromatik dalam aliran darah yang terdiri dari metabolisme beberapa makanan atau pengeluaran produk dari metabolisme sel, contohnya pada pecandu alkohol, penderita diabetes melitus, dan gangguan fungsi ginjal. Selain itu, kondisi yang juga berhubungan dengan halitosis yaitu penyakit jantung dan bronkus, sinusitis, tonsilitis, penyakit hati, gangguan gastrointestinal, dan gagal ginjal. ${ }^{13,14}$

\section{Tabel 1. Klasifikasi Halitosis ${ }^{15,16}$}

\begin{tabular}{|c|c|c|}
\hline & Klasifikasi & Gambaran umum \\
\hline \multirow[t]{4}{*}{ I. } & $\begin{array}{l}\text { Genuine halitosis } \\
\text { a. Halitosis fisiologis }\end{array}$ & $\begin{array}{l}\text { Halitosis jelas, dapat dirasa } \\
\text { 1. Halitosis muncul akibat proses pembusukan di dalam mulut. Tidak } \\
\text { ada penyakit spesifik atau kondisi patologis. } \\
\text { 2. Umumnya berasal dari tepi posterior lidah } \\
\text { 3. Halitosis berhubungan dengan makanan }\end{array}$ \\
\hline & b. Halitosis patologis & \\
\hline & i. Oral & $\begin{array}{l}\text { 1. Halitosis disebabkan oleh penyakit, kondisi patologis atau malfungsi } \\
\text { dari jaringan mulut } \\
\text { 2. Halitosis berasal dari lapisan lidah, kombinasi dari keadaan patologik } \\
\text { (penyakit periodontal, serostomia) }\end{array}$ \\
\hline & ii. Ekstraoral & $\begin{array}{l}\text { 1. Bau berasal dari nasal, perinasal dan laring } \\
\text { 2. Bau berasal dari saluran napas dan cerna } \\
\text { 3. Bau berasal dari dalam tubuh (diabetes, hepatic cirrhosis, uremia) }\end{array}$ \\
\hline II. & Pseudohalitosis & $\begin{array}{l}\text { 1. Bau tidak dirasakan oleh orang lain, meskipun pasien mengeluh } \\
\text { tentang keadaannya } \\
\text { 2. Dapat dilakukan penyuluhan (dukungan, pendidikan dan keterangan } \\
\text { dari hasil pemeriksaan) dan pengukuran kebersihan mulut. }\end{array}$ \\
\hline III. & Halitofobia & $\begin{array}{l}\text { 1. Dirasa mulutnya berbau walaupun telah dilakukan pemeriksaan } \\
\text { 2. Tidak ada pemeriksaan fisik yang jelas tentang halitosis ini. }\end{array}$ \\
\hline
\end{tabular}

Makalah ini bertujuan untuk memaparkan hasil penelitian mengenai tingkat keparahan halitosis pada manula pemakai gigitiruan 


\section{BAHAN DAN METODE}

Pada penelitian jenis cross sectional ini terdapat dua macam variabel, yaitu variabel sebab dan variabel akibat yang dilakukan secara bersama-sama atau sekaligus. Penelitian ini dilakukan di wilayah Makassar. Metode sampling yang digunakan adalah non-random (selective sampling) yaitu pemilihan sampel ditentukan berdasarkan pertimbangan peneliti, populasi yang terjangkau dan memenuhi kriteria rumur $\geq 60$ tahun, memakai gigitiruan, jumlah sampel 50 orang, dan tidak menderita penyakit sistemik.

\section{Kriteria halitosis ${ }^{17}$}

Skor 0 : tidak ada bau (bau tidak dapat diketahui)

Skor 1 : bau diragukan (bau dapat dirasa walaupun pemeriksa tidak mengenalinya sebagai bau mulut)

Skor 2 : bau sedikit (bau masih dipertimbangkan, bau dapat dirasa)

Skor 3 : bau sedang (bau dapat dirasakan)

Skor 4 : bau keras (bau dapat dirasakan dan disadari oleh pemeriksa)

Skor 5 : bau hebat (bau dapat dirasakan dan tidak disadari oleh pemeriksa)

Pada penelitian ini dilakukan wawancara pada sampel. Setiap sampel diberikan kuesioner, yang pengisiannya dibantu oleh peneliti sendiri. Pemeriksaan pada sampel lanjut usia dilakukan selain dengan mengoleskan kapas steril pada permukaan gigitiruannya, lalu dihidu oleh pemeriksa (bau usap). Selain itu juga dilakukan dengan mencium bau napas sampel (bau hembus). Selanjutnya dilakukan skoring bau dari setiap sampel.

\section{HASIL PENELITIAN}

Dari penelitian yang dilakukan terhadap manula di Makassar diperoleh hasil sebagai berikut:

Tabel 2. Distribusi manula menurut jenis kelamin di Makassar

\begin{tabular}{ccc}
\hline Jenis Kelamin & $\begin{array}{c}\text { Frekuensi } \\
(\mathbf{n})\end{array}$ & $\begin{array}{c}\text { Persentase } \\
(\boldsymbol{\%})\end{array}$ \\
\hline Laki-laki & 17 & 34 \\
Perempuan & 33 & 66 \\
Jumlah & 50 & 100 \\
\hline
\end{tabular}

Pada tabel 2, terlihat bahwa manula perempuan lebih banyak yang menggunakan gigitiruan dibandingkan dengan manula laki-laki, yaitu $66 \%$ perempuan dan laki-laki $34 \%$.

Tabel 3. Distribusi manula menurut jenis gigitiruan

\begin{tabular}{ccc}
\hline Jenis gigitiruan & $\begin{array}{c}\text { Frekuensi } \\
(\mathbf{n})\end{array}$ & $\begin{array}{c}\text { Persentase } \\
(\boldsymbol{\%})\end{array}$ \\
GTSL & 25 & 50 \\
GTP & 24 & 48 \\
Cekat & 1 & 2 \\
\hline
\end{tabular}




\begin{tabular}{ccc}
\hline Jumlah & 50 & 100 \\
\hline
\end{tabular}

Pada tabel 3 terlihat bahwa 50\% dilihat jenis gigitiruan yang dipakai dimana jumlah gigitiruan sebagian lepasan sebanyak 25 dengan persentase $50 \%$, gigitiruan penuh sebanyak 24 dengan persentase $48 \%$, dan gigitiruan cekat sebanyak 1 dengan persentase $2 \%$.

Tabel 4. Distribusi manula menurut lama pemakaian gigitiruan

\begin{tabular}{ccc}
\hline $\begin{array}{c}\text { Lama pemakaian } \\
\text { gigitiruan }\end{array}$ & $\begin{array}{c}\text { Frekuensi } \\
(\mathbf{n})\end{array}$ & $\begin{array}{c}\text { Persentase } \\
(\%)\end{array}$ \\
\hline$<1$ tahun & 14 & 28 \\
1 tahun & 5 & 10 \\
$>$ 1 tahun & 31 & 62 \\
Jumlah & 50 & 100 \\
\hline
\end{tabular}

Dari tabel 4 terlihat bahwa $62 \%$ sampel manula pengguna gigitiruan telah menggunakan gigitiruannya selama lebih dari satu tahun. Selebihnya menggunakan gigitiruan satu tahun atau dari satu tahun.

Tabel 5 Keparahan Bau Hembus Lansia Pemakai Gigitiruan

\begin{tabular}{|c|c|c|}
\hline Kategori Bau & $\begin{array}{c}\text { Frekuensi } \\
\text { (n) }\end{array}$ & $\begin{array}{c}\text { Persentase } \\
(\%)\end{array}$ \\
\hline Tidak ada bau & 12 & 24 \\
Bau diragukan & 7 & 14 \\
Bau sedikit & 23 & 46 \\
Bau sedang & 7 & 14 \\
Bau keras & 1 & 2 \\
Bau hebat & 0 & 0 \\
\hline Jumlah & 50 & 100 \\
\hline
\end{tabular}

Tabel 5 menggambarkan persentase bau hembus pada pemakaian gigitiruan lanjut usia, dimana terlihat jelas bahwa sebagian besar pemakai gigitiruan menimbulkan bau sedikit sebanyak 23 dengan persentase $46 \%$ dan menimbulkan bau keras sebanyak 1 dengan persentase $2 \%$. Lansia yang memakai gigitiruan tapi tidak menimbulkan bau sebesar $24 \%$ sedangkan bau diragukan dan bau sedang sama-sama sebesar $14 \%$.

Tabel 6 Keparahan Bau Usap Lansia Pemakai Gigitiruan

\begin{tabular}{|c|c|c|}
\hline Kategori Bau & $\begin{array}{c}\text { Frekuensi } \\
(n)\end{array}$ & $\begin{array}{c}\text { Persentase } \\
(\%)\end{array}$ \\
\hline
\end{tabular}




\begin{tabular}{|c|c|c|}
\hline Tidak ada bau & 12 & 24 \\
Bau diragukan & 0 & 0 \\
Bau sedikit & 7 & 14 \\
Bau sedang & 23 & 46 \\
Bau keras & 7 & 14 \\
Bau Herat & 1 & 2 \\
\hline Jumlah & & 100 \\
\hline & 50 & \\
\hline
\end{tabular}

Pada tabel diatas, terlihat persentase bau usap pada pemakaian gigitiruan lanjut usia. Terlihat jelas bahwa sebagian besar pemakai gigitiruan menimbulkan bau sedang sebanyak 23 dengan persentase $46 \%$ dan menimbulkan bau hebat sebanyak 1 dengan persentase $2 \%$. Lansia yang memakai gigitiruan tapi tidak menimbulkan bau sebesar 24\% sedangkan bau sedikit dan bau keras sama-sama sebesar $14 \%$.

\section{PEMBAHASAN}

Tempat yang paling banyak dihuni oleh bakteri penyebab halitosis adalah celah diantara papilla lidah bagian belakang. Jumlahnya akan meningkat dalam keadaan mulut kering. Telah diketahui bahwa pada lansia sering terjadi xerostomia. Bakteri anaerob mudah berkembang dalam kondisi kekurangan saliva yang mengandung oksigen. Pemakaian gigitiruan pada lansia dapat menyebabkan halitosis karena gigitiruan resin akrilik mempunyai sifat dapat menyerap cairan yang berasal dari bahan makanan dan minuman yang melekat dan masuk ke plat gigitiruan yang akan meninggalkan bau yang kurang sedap. ${ }^{(5)}$

Chamberlain et all, bila terdapat debris makanan yang lunak menempel pada gigitiruan hal ini dapat dengan mudah dibersihkan dengan cara menyikat dan berkumur. Deposit yang keras seperti kalkulus yang menempel pada gigitiruan sukar dihilangkan. Komposisi dari deposit ini pada setiap individu sangat bervariasi, apabila tidak dibersihkan akan menimbulkan bau tidak sedap. $^{(5)}$

Dari hasil penelitian, lama pemakaian gigitiruan dapat mempengaruhi munculnya halitosis, dimana pemakaian gigitiruan lebih dari 1 tahun lebih banyak menimbulkan halitosis dibanding dengan pemakaian 1 tahun dan kurang dari 1 tahun. Makin lama pemakaian gigitiruan 
maka kontak dengan makanan, minuman dan cairan mulut juga makin sering, sehingga akan lebih mudah plak bakteri berkembang. Ditambah dengan berkurangnya kordinasi otot pada lansia maka pembersihan gigitiruan akan lebih sulit. Cahn, menyimpulkan dalam penelitiannya bahwa kehadiran plak (denture plaque) yang disebabkan karena kumpulan mikroorganisme dan matrik glikoprotein serta polisakarid yang menempel pada permukaan basis gigitiruan. Proses terbentuknya plak dimulai dengan terbentuknya pelikel yang mengandung glikoprotein saliva yang menempel pada gigitiruan. Setelah pelikel terbentuk, mikroorganisme segera membentuk koloni dan akan meningkat secara bertahap. Pembentukannya dipercepat dengan oral hygiene yang jelek. Hal inilah yang menimbulkan bau yang kurang sedap. ${ }^{(5)}$

Dari hasil penelitian, jenis gigitiruan dapat mempengaruhi munculnya halitosis, dimana jenis GTSL lebih banyak menimbulkan halitosis dibanding dengan jenis GTP dan jembatan. Deposit oral dan mikroorganisme yang melekat pada gigitiruan dapat memberikan efek yang tidak diharapkan. Perlekatan bahan itu sendiri tidak estetik dan tidak nyaman dari segi taktil, rasa, dan bau. Selain itu endapan plak mikrobial, kalkulus, dan sisa makanan pada gigitiruan dapat menyebabkan denture stomatitis, angular cheilitis, dan mempercepat rusaknya bahan gigitiruan $^{(18)}$. Pada GTSL deposit oral dan mikroorganisme lebih mudah terbentuk karena ada cengkeram dan gigi natural yang sisa serta adanya celah-celah antara plat gigitiruan dan gigi natural yang tersisa. Selain itu karena lansia agak sulit dalam pembersihan gigitiruan dan gigi natural yang masih tersisa dalam rongga mulut karena gangguan kordinasi syaraf serta keadaan xerostomia yang biasa menyertai lansia.

Dari tabel 8,9 diperoleh bahwa tingkat halitosis dengan deteksi bau usap dan deteksi hembus adalah $46 \%$ dengan kategori bau sedang. Kesamaan nilai ini mungkin disebabkan pada waktu pasien menghembuskan nafasnya bau tidak terlalu tercium oleh pemeriksa karena hembusan nafas pasien telah bercampur dengan udara bebas. Oleh karena itu, cara yang paling efisien untuk mendeteksi bau yaitu deteksi bau usap. Selain itu, dengan cara ini kita juga dapat 
melihat kebersihan gigitiruan tersebut. Pemeriksaan bau mulut dapat juga dilakukan dengan menggunakan alat seperti tongue cleaner, oral chroma dan halimeter.

Gayford berpendapat bahwa pada dasarnya pencegahan halitosis merupakan perawatan dari keadaan penyebab. Terutama terhadap kebersihan mulut, setiap selesai makan. Kebersihan mulut merupakan bagian yang penting dari program pemeliharaan gigitiruan, sedang keberhasilan perawatan gigitiruan salah satunya tergantung pada tingkat kebersihan mulut itu. Telah membudaya pada masyarakat bahwa kumur-kumur dipergunakan sebagai salah satu metode pemeliharaan kebersihan mulut. Efek mekanis dari gerakan kumur itu sendiri terhadap daya pelepasan deposit lunak didalam rongga mulut memang sangat memuaskan. Berkumur secara seksama dengan menggunakan air bersih dapat membantu membersihkan mulut walaupun efektifitasnya kecil. ${ }^{(5)}$

Untuk mengurangi halitosis, Hipocrates menyarankan berkumur cairan rempah dan anggur. Pengobatan lain dengan mengunyah biji lada (the Talmud) dan parsley. Penduduk mediterania mengunyah karet pohon Pistacia Lectiscus ${ }^{(5)}$. Menurut Suwondo dkk., upaya untuk memanfaatkan daun sirih (Piper betle L) sebagai sumber bahan obat dalam Kedokteran Gigi, maka telah dilakukan suatu penelitian terhadap 40 jenis tumbuhan yang banyak digunakan masyarakat untuk berbagai keperluan yang berhubungan dengan kesehatan gigi dan mulut. Hasil penelitian menunjukkan bahwa daun sirih merupakan salah satu dari 13 jenis tumbuhan yang memiliki aktifitas anti bakteri paling tinggi. ${ }^{(4)}$ Dizaman sekarang, untuk kebersihan gigi digunakan pasta yang mengandung zat pembersih dan penyegar, mengunyah permen karet penyegar dan obat kumur ${ }^{(5)}$.

Pemakaian gigitiruan pada lansia harus dijaga kebersihannya agar tidak menimbulkan halitosis. Bahan dasar gigitiruan yaitu resin akrilik memiliki kemampuan menyerap cairan, yang dilakukan dengan mudah oleh energi internal dan polaritas karboksil dalam resin. Oleh karena sifat ini, gigitiruan bila diletakkan dalam mulut atau direndam dalam larutan desinfektan, dapat 
mengabsorbsi saliva dan bahan desinfektan tersebut. Telah diketahui bahwa dalam saliva mengandung protein yang dapat diurai oleh bakteri menghasilkan bau yang tidak sedap. Pengetahuan dini terhadap kesehatan gigi dan mulut pada warga masyarakat sangat penting diketahui untuk mencegah terjadi halitosis, sehingga ketika nantinya mereka menjadi golongan lansia, setidaknya ada dasar pengetahuan. Pengetahuan dasar tentang kesehatan gigi dan mulut yang dimasukkan dalam kurikulum sekolah-sekolah merupakan tindakan yang tepat bagi Pemerintah untuk mencegah hal ini terjadi.

\section{SIMPULAN DAN SARAN}

\section{A. Simpulan}

1. Tingkat halitosis dengan deteksi bau usap $46 \%$ dengan kategori bau sedang, deteksi bau hembus $46 \%$ dengan kategori bau sedang dan deteksi bau jilat $48 \%$ dengan kategori sedikit.

2. Pemakaian gigitiruan dapat menyebabkan halitosis.

3. Jenis gigitiruan dapat mempengaruhi munculnya halitosis, dimana jenis GTSL lebih banyak menimbulkan halitosis.

4. Lama pemakaian gigitiruan mempengaruhi terjadinya halitosis.

\section{B. Saran}

Perlunya penyuluhan kesehatan gigi dan mulut pada lansia tentang pemelihaan kebersihan gigitiruannya.

\section{DAFTAR PUSTAKA}

1. Bau mulut mengancam kesehatan gigi. Available from: http://www.cybertokoh.com. Accessed November 16, 2006. 
2. Menangkis bau mulut. Available from: http://www.promosikesehatan.com. Accessed November 13, 2006.

3. Darwita RR, Rahardjo A, Valeridiana, Prananto, Agung A. Hubungan terjadinya halitosis dan penyakit periodontal. Makassar: Dentofasial Jurnal Kedokteran Gigi; Februari 2003: 275.

4. Winasa IG. Perubahan jaringan rongga mulut pada usia lanjut. Vol. $1^{\text {st }}$. No. $4^{\text {th }}$. Surabaya: Majalah Kesehatan Gigi Indonesia; Januari 1995: 16-17.

5. Soeprapto H. Halitosis pada pemakaian gigitiruan lengkap usia lanjut. Vol. $1^{\text {st }}$. No. $7^{\text {th }}$. Surabaya: Majalah Kesehatan Gigi Indonesia; Oktober 1995: 7-9.

6. Hasibuan S. Keadaan-keadaan dirongga mulut yang perlu diketahui pada usia lanjut. No. $4^{\text {th }}$. Medan: Majalah Kedokteran Gigi USU; Januari 1998: 40-4.

7. Gayford JJ, Haskell R. Penyakit mulut. $2^{\text {nd }}$ ed. In: Lilian Yuwono, editor. Jakarta: EGC; 1993: 177-183.

8. Mustaqimah DN. Bakteri yang berkaitan dengan halitosis. No. $1^{\text {st }}$. Jakarta: Dentofasial Jurnal Kedokteran Gigi; Februari 2003: 82.

9. Bau mulut tak sebatas urusan kosmetik. Available from: http://www.202.155.5.44/index.php. Accessed November 16, 2006.

10. Lambri SE. Halitosis salah satu pengganggu estetika gigi dan mulut serta penanggulangannya. Vol. $8^{\text {th }}$. No. $1^{\text {st }}$. Surabaya: Jurnal Kedokteran Gigi; Juli 1996: 13.

11. Halitosis and oral malodour. Fdi world [journal online]. Available from: http://www.google.com. Accessed Februari 17, 2007.

12. Newman MG, Takei HH, Carranza FA. Clinical periodontology. $9^{\text {th }}$ ed. Philadelphia: W.B Saunders Company; 2002: 436-7.

13. Sonis ST, Fazio RC, et all. Oral medicine secrets. Philadelphia: Hanley \& Belfus Inc; 2002: 163. 
14. Sonis ST. Dental secrets. $3^{\text {rd }}$ ed. Philadelphia: Hanley \& Belfus Inc; 2003: 15-6.

15. Examination, classification, and treatment of halitosis; clinical perspectives. Available from http://www.cda.adc.com. Accessed Februari 25, 2007.

16. Halitosis: Breath behaving badly. Available from: http://www.nurseslearning.com. Accessed Juni 13, 2007.

17. Classification of halitosis. Available from: http://www.thejcdp.com.htm. Accessed Februari 25, 2007.

18. Basker RM, Davenport JC, Tomlin HR. Perawatan prostodontik bagi pasien tak bergigi. Ed 3. Jakarta: EGC; 1996. 216. 